\title{
UVB and UVA effects on both aquatic organisms enzymes and enzymatic reactions made by pure enzymes Liviu-Daniel Galatchi*
}

\author{
Address: Faculty of Natural Sciences, Ovidius State University, Constanta, Romania \\ Email: Liviu-Daniel Galatchi* - galatchi@univ-ovidius.ro \\ * Corresponding author
}

from Cell Biology of Nitric Oxide and Cell Death in Plants

Yalta, Ukraine, 8-II September 2004

Published: 31 May 2005

BMC Plant Biology 2005, 5(SuppI I):SI7 doi:I0.II 86/I47I-2229-5-SI-SI7

In our research we found out that ultraviolet B irradiation increases the activity of the pure hydrolase ( $\beta$-amylase, E.C.3.2.1.1) and Merck peroxidase (E.C.1.11.1.7) by free radicals generated from synthetic polymers walls of the experimental tubes. The activation was higher after UVB irradiation than after UVA. UVB and UVA increase the intensity of cell structure destruction by free radical-activated hydrolase determined on nude alga Tetraselmis suecica, cultivated bacteria Escherichia coli $\mathrm{O}_{157}$ (exponential phase), Acinetobacter calcoaceticus and total germs after the short time of exposure in the thermo-stated conditions.

The nude alga T. suecica was more resistant and stores starch and lipids. This alga was able to convert the energy of irradiation into chemical energy of synthetic products. Some individuals of $T$. suecica become encysted through creating of thick inhomogeneous sub-silique, under which a new silique appears. Other cells increase their glucide (intra-plastid starch granules) and lipid reserves of provisions (oleosoma appear in the central part of the cell and affect the tillakoid lamellar structure; plasto-globules appear as well). T. suecica, which lives in the surface region of the sea's waters, has 10 times higher growth resistance to natural solar irradiation. After $10 \mathrm{~min}$. of exposure, it succeeds to convert energy of the absorbed radiation into the energy of the provision products stored as starch and lipid granules.

Cultivated bacteria on poor specific media developed very slowly after irradiation (transmittance $300-800 \mathrm{~nm}$ ). If the bacteria were cultivated on reach media, which absorb UV (Martin medium) they are developed by $\mathrm{n}^{3}$ rule, instead $\mathrm{n}^{2}$ in the first stage, after irradiations of bacteria culture (transmittance 235-800 $\mathrm{nm}$ ). 